\title{
Archaeological Investigation of the Southeast Building Complex, Old Ursuline Academy Campus, 41BX235, San Antonio, Texas
}

Courtenay J. Jones

Follow this and additional works at: https://scholarworks.sfasu.edu/ita

Part of the American Material Culture Commons, Archaeological Anthropology Commons, Environmental Studies Commons, Other American Studies Commons, Other Arts and Humanities Commons, Other History of Art, Architecture, and Archaeology Commons, and the United States History Commons

Tell us how this article helped you.

This Article is brought to you for free and open access by the Center for Regional Heritage Research at SFA ScholarWorks. It has been accepted for inclusion in Index of Texas Archaeology: Open Access Gray Literature from the Lone Star State by an authorized editor of SFA ScholarWorks. For more information, please contact cdsscholarworks@sfasu.edu. 


\section{Archaeological Investigation of the Southeast Building Complex, Old Ursuline Academy Campus, 41BX235, San Antonio, Texas}

\section{Creative Commons License}

\section{(c) (1) \&}

This work is licensed under a Creative Commons Attribution-NonCommercial 4.0 International License 


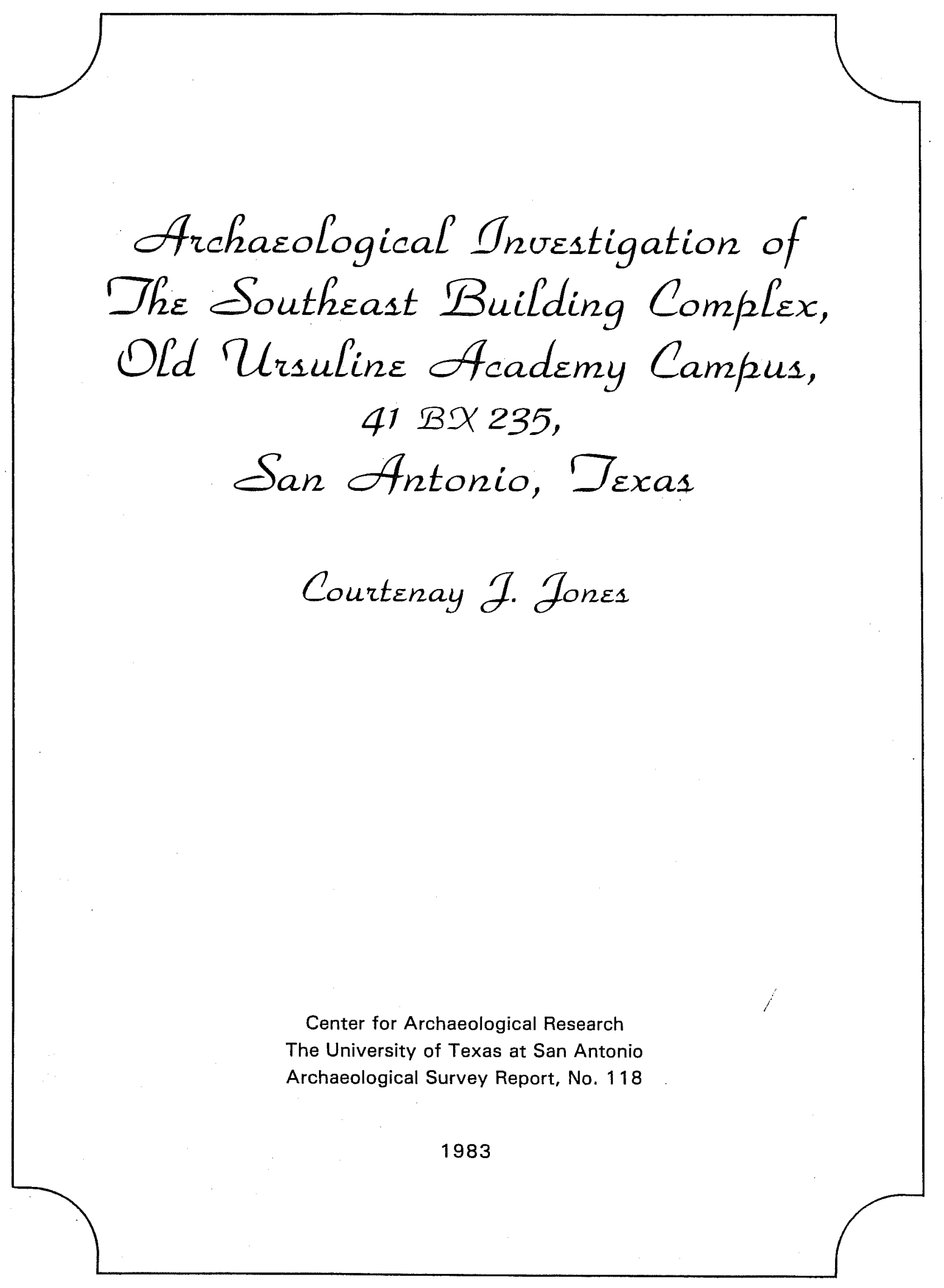





\title{
ARCHAEOLOGICAL INVESTIGATION OF \\ THE SOUTHEAST BUILDING COMPLEX, OLD URSULINE ACADEMY CAMPUS, \\ 41 BX 235, \\ SAN ANTONIO, TEXAS
}

\author{
Courtenay J. Jones
}

Center for Archaeological Research The University of Texas at San Antonio

Archaeological Survey Report, No. 118

1983

UTSA - Center for Archaeological Research 



\section{ABSTRACT}

This report outlines the results of an archaeological investigation associated with a complex of buildings located in the southeast portion of the 0ld Ursuline Academy campus, San Antonio, Texas. An analysis of the physical characteristics of the buildings is provided. A proposed history based on field observations and archival research is offered. Additional information is presented regarding legends concerning the early years of Ursuline Academy. 
Abstract ............................ List of figures. . . . . . . . . . . . . . i i i Acknowledgments. ................... iv Introduction ....................... 1 Property Background. . . . . . . . . . . . . . . . 1 Early Construction . . . . . . . . . . . . . . . . 5 Original Building .................. 5 Subsequent Buildings. . . . . . . . . . . . . . . 6 The Study Area . . . . . . . . . . . . . . . . . 7 Building 1. ...................... 7 Building 2. . . . . . . . . . . . . . . . 10 Building 3...................... 12

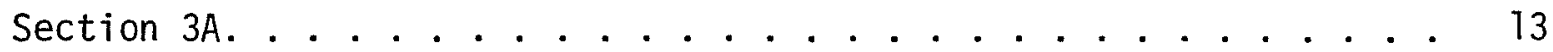
Excavations..................... 16 Column Profiles...................... 16

Test Pits in Building 2................. 17

Test Pits in Building $3 \ldots . . . . . . . . . . . .17$

Block Excavations ................... . 19

The Artifacts. . . . . . . . . . . . . . . . . 20 Interpretations. . . . . . . . . . . . . . . . . 21

Building 1.................... 21

Building 2. . . . . . . . . . . . . . . . 21

Building 3. . . . . . . . . . . . . . . . 22

Section 3A...................... 23 
Conclusions ........................ 23

Recommendations ..................... 25

References Cited. . . . . . . . . . . . . . . 26

Appendix: Contract Between John Campbe11 and the Ursuline Order

for the Construction of Building $1 \ldots . . . . . .30$

\section{LIST OF FIGURES}

1. 01d Ursuline Academy Campus at the Turn of the Century. . . . . . . 4

2. 01d Ursuline Academy, Southeast Building Complex. . . . . . . . . 8

3. 01d Ursuline Academy, Views of Southeast Building Complex . . . . . . 9

4. 01d Ursuline Academy, Southeast Building Complex, Building 3, Area A . 14

5. 01d Ursuline Academy, Southeast Building Complex, Building 3, Area A 15

6. 01d Ursuline Academy, Southeast Building Complex, Building $2 \ldots 18$ 


\section{ACKNOWLEDGMENTS}

The author would like to express his appreciation to those people who contributed to this report. A special thanks to Mrs. Donald Saunders, Vice President of Southwest Craft Center, who provided background information for this report. Thanks also to Francine Rowden who provided copies of the original Giraud letters to the Center for Archaeological Research files. Gratitude is also expressed to I. Waynne Cox and Anne A. Fox who not only volunteered in the field and research activities, but also provided assistance in preparing this report. A special thank you to the library staffs of both the Daughters of the Republic of Texas and the San Antonio Conservation Society, who, once again, generously made their resources and files available to the project staff. Dr. Thomas R. Hester administered this job as Principal Investigator, and Jack D. Eaton served as Co-Principal Investigator. The contributions of these people are gratefully acknowledged. 


\section{INTRODUCTION}

An archaeological investigation of a complex of buildings situated on the southeast corner of the 01d Ursuline Academy campus, 41 BX 235, San Antonio, Texas, was conducted by employees of the Center for Archaeological Research, The University of Texas at San Antonio, Texas (CAR-UTSA). The 01d Academy is listed on the National Register of Historic Places. The work was accomplished in accordance with the National Historic Preservation Act of 1966, as amended. Work was coordinated under the National Park Service, Department of the Interior. The project was accomplished through a contract between the CAR and the Southwest Craft Center in correspondence dated February 17, i982. The project was administered by Dr. Thomas R. Hester, Director of the Center for Archaeological Research and Jack D. Eaton, Associate Director. Mrs. Donald Saunders, Vice President of the Southwest Craft Center, served as liason between the CAR and the Southwest Craft Center. Field activities and site interpretation were directed by James $E$. Ivey, Research Associate at the CAR. Field activities and archival research were accomplished by Anne A. Fox, Research Associate; I. Waynne Cox, Technical Staff Assistant; and Courtenay J. Jones, Technical. Staff Assistant.

\section{PROPERTY BACKGROUND}

In 1848, Bishop John M. Odin, Vice-Perfect for the district of Texas (Clark 1974:2; Garner n.d.:3) completed the necessary actions which would permit the establishment of a convent in San Antonio. Such a facility was requested and encouraged by Father Dubuis (Edwards n.d.:21), parish priest in Castroville, who later became "State Supervisor of curates with headquarters in San Antonio" (ibid.). This convent in San Antonio was Bishop Odin's second effort regarding the Ursulines in Texas. Further details concerning the history of the Ursulines are recorded in Clark (1974:2).

The site selected for the convent was situated on the San Antonio River, a location which was, at that time, north of the city of San Antonio. The earliest transaction involving Bishop Odin occurred September 20, 1840, when he agreed to purchase the property from Ludovic Colquhoun for $\$ 2200$. This agreement was dependent upon Colquhoun obtaining a ". . f ful1, perfect, and indefeasible title..." (BCDR Vo1. A-2:336, Sept. 20, 1840). A down payment of $\$ 1100$ was made at this time by Bishop Odin (ibid.). This contingency was apparently related to earlier transactions between Colquhoun and Erasmo Seguin that had not been settled. On July 11, 1844, Colquhoun obtained clear title to the property from Seguin in exchange for a payment of $\$ 600$. The property is described as:

A11 that piece or parcel of land or lot of ground lying and being situated on the San Antonio River and being one of the out lots of the City of San Antonio and contiguous thereto and being bounded on the east as described in the original deed [emphasis author's] to said Seguin by the river and on the South by the same, and on the North by the land of Juan Manuel Zambrano dec'd and on the west by that of Juan Antonio Urrutia dec'd and commencing at a stake placed at the edge of the river on the upper side or mouth of a drain which runs into the river just above a lime kiln. Thence-thirty two degrees east two hundred and five varas to a stake from which a cottonwood tree about sixteen inches in diameter bears North 
two and one fourth degrees east. Another bears North five and one half degrees west and a third, about twenty inches in diameter bears North forty four degrees west. The middle window of Ambrocia Rodriquez "house" in the upper story, in the aforesaid city bears South eight degrees east and the Front steeple of the church bears South fifteen degrees west. Thence South sixty five degrees east to the river. Thence down said river with its meanderings to the place of beginning. . (BCDR Vo1. D2:137, Ju7y 11, 1844).

Although archival research was unable to locate the original deed of Erasmo Seguin, he was an important individual in San Antonio, both in real estate and public service. A brief biographic account of Seguin and his activities is contained in Chabot (1937:118-129). Seguin was also instrumental in public education. Chabot (ibid.:119) recounts Seguin's role in establishing a school in San Antonio. Several references to a piece of property used as a school and owned by Seguin and subsequently confiscated by the Spanish government during the "rebel uprising" in 1812 are contained in the Rebel Property files at the office of the Bexar County Archivist. These accounts refer to the inventory, appraisement, and subsequent return of this property which was located in the vicinity of the present-day courthouse (BCA-RP Vol. $4: 2,5,8$, 1817a; Vo1. 7:2, 1817b; Vo1. 6:1, June 24, 1918a; Vol. 9:13, July 5, 1819b). This property is not believed to be associated with the convent.

In September 1848, Bishop 0din obtained a full title to the property from Colquhoun in exchange for $\$ 1000$, presumably a slightly reduced balance from the 1840 transaction. The property in this transaction is described as:
- . by the river and on the South by the same on the North by the lands of Juan Manuel Zambrano dec. on the west by those of Juan Ant ${ }^{0}$ Mastia dec. and commencing at a stake planted on the edge of the river on the upper side of a drain which runs into the area above two lime kilns--Thence North ten degrees west 75 varas to another stake thence $N 32^{\circ} \mathrm{E} 205$ varas to a stake from which a cottonwood tree about 16 inches in dia bears $N 2 \frac{1}{4}^{\circ} \mathrm{E}$ another bears $N 5 \frac{1}{2} \mathrm{~W}$ and a third of 20 inches in dia bears $\mathrm{N} 44 \frac{1}{4} \mathrm{~W}$ and the front steeple of the church bears $\mathrm{S} 15 \mathrm{~W}$. Thence $\mathrm{S} 65 \mathrm{E}$ to the river. Thence down said river with its meanders to the beginning (BCDR Vo1. G1:390, Sept. 26, 1848).

This property was used by Bishop Odin as collateral in a transaction with Jose Cassiano in 1846. Three parcels of land were mortgaged to Cassiano for $\$ 4000$ (BCDR Vo1. E-2:17-19, 0ct. 31, 1846). The convent property was released from this mortgage on October 11, 1848 (BCDR Vol. G-1:437, Oct. 11, 1848), permitting another mortgage to be issued using this property as collateral. This second mortgage was made to Edward Dwyer, Bryan Callaghan, and Francois Guilbeau on October 12, 1848, in exchange for $\$ 500$ each (BCDR Vo1. G-1:440-441, 0ct. 12, 1848). This transaction is significant and is discussed further in the EARLY CONSTRUCTION section of this report.

The next transaction regarding this property occurred on May 20, 1853, when Bishop Odin sold the property to five nuns representing the Ursuline Order. The purchase price was $\$ 1.00$. The property description in this transaction refers to street references: 
- a certain tract of Tand situated in the Northern part of the City of San Antonio in the state of Texas on the right bank of the San Antonio River bounded as follows; beginning at a stake set on the bank of said river [about five varas from the water] on the upper line of a street 12 varas wide running down to the river, which separates this property from a lot from the estate of Wilitiam Elliot. Thence with said street- $\mathrm{N} 251 / 2 \mathrm{~W}$. 60 varas to the corner of another street--Thence with the last mentioned street $\mathrm{N} 33^{\circ} \mathrm{E} 175$ varas and $N 551 / 2^{\circ}$ E $433 / 4$ varas. Thence along a street running between this tract and the property of $\mathrm{J}$. A. Pascal and which is 20 varas wide $S 351 / 2^{\circ}$ E 140 varas--Thence along the S.E. side of another strate [street ?] N $551 / 2$ E 95 varas--this street being also 20 varas wide--Thence $S .657 / 8^{\circ}$ E $283 / 4$ varas thence $S .353 / 4^{\circ} \mathrm{E}$ 80 varas to a Pecan about 2 feet in diameter on the bank of the San Antonio River just beis--- [beside?] a sharp bend to the Eastward and down said river with all its meanders including the Rincón de Flores now being rented out as a garden to Joseph Seyer to the place of beginning (BCDR Vol. L2:29-30, May 20, 1853).

The five nuns who purchased the property were: Sister St. Seraphine Ray, Supervisor; Sister St. Claire Kaskery, Ass't. Supervisor; Superior Sister St. MichaeI Jourdain, Treasurer; Sister St. Ange1; and Sister St. Gertrude, Counselor.

As mentioned in this latter deed transaction, apparently not all of the property purchased was controlled by the convent. The Rincôn de Flores rented out to Joseph Seyer was probably the land encompassed by a large meander in the river (see Fig. 1). Reference to a rental or sublease arrangement is made by Sister M. Augustine Joseph (McDowe11 1977:236) in a letter written October 1852, which mentions the agreement having two more years to run. Another letter written December 16, 1852, by Sister M. Patrick Joseph mentions a German tenant occupying part of their land (ibid.:266). These two sisters were two of the three nuns, recruited by Bishop Odin in Europe (Clark 1974:3), who joined the initial group of nuns shortly after the convent was established. The use of this meander as a garden spot apparently continued for some time, as Edwards (1981:3) refers to the ". . . Southeast breeze after passing over the garden meander. ..." Her description of walks through the garden also fit this part of the property (ibid.).

Portions of 1 and were added or sold, as dictated by the needs of the convent in subsequent years (BCDR Vol. K1:218, Oct. 25, 1850; Vol. 1:42, Nov. 25, 1872; Vol. 1:365, 394, May 11, 1872). The remainder of the property was sold by the Ursuline Order in New Orleans to the San Antonio Convent (BCDR Vol. 34:210, May 2, 1884).

With the relocation of the Ursuline Academy to a new location on Vance Jackson Road in 1961 (Clark 1974:3), the property passed through the hands of various owners, including the San Antonio Conservation Society in 1965. In 1971, the Southwest Craft Center acquired possession of part of the land on which the campus building complex is located (ibid.). The property encompassing the study area of this report was acquired by the Southwest Craft Center in 1979 from Mrs. C. B. Negley (Mrs. Donald Saunders, personal communication). As a result of this final purchase, all of the main campus buildings are now owned by the Southwest Craft Center. 


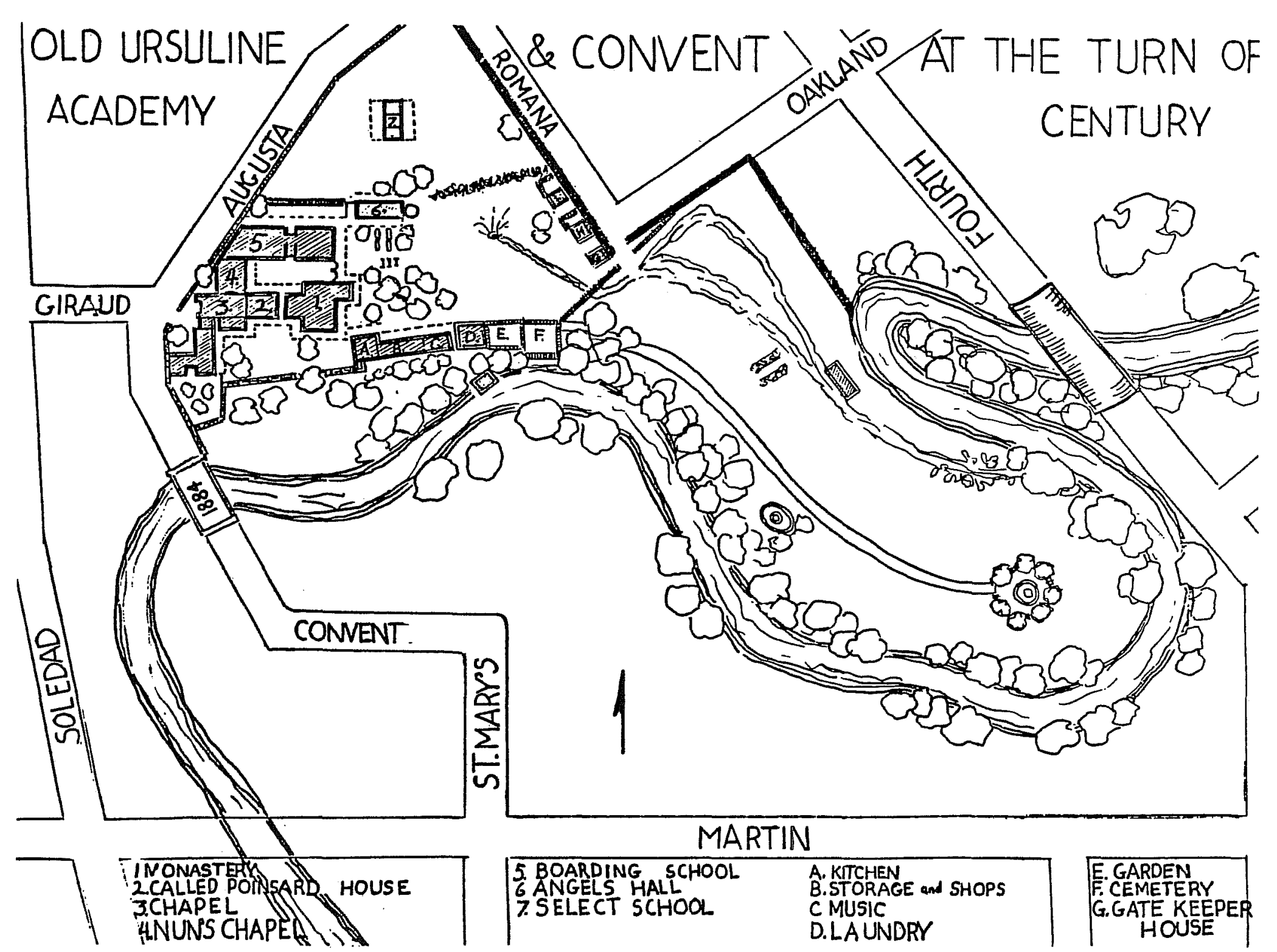

Figure 1. Oed Ursuline Academy Campus at the Turn of the Century. Adapted from research by Mary Green and Emily Edwards. On file at the Daughters of the Republic of Texas Library. 


\section{EARLY CONSTRUCTION}

\section{Original Building}

Following his purchase of the convent property, Bishop Odin mortgaged the property to Edward Dwyer, Francois Guilbeau, and Bryan Callaghan in return for a loan of $\$ 1500$. The proceeds from this mortgage were evidently placed in the hands of Francois Giraud by Bishop Odin for the purpose of constructing the first building to be used by the convent. Giraud was a surveyor and architect who lived in San Antonio. His contributions to the development of San Antonio are discussed by Ramsde11 (1968:32-34) and Edwards (n.d.). Sheridan. (1938:216) mentions that the Bishop ". . . had had a house erected for them. . . ." Garner (n.d.:4-8) records the translation of a letter written in French by an unidentified nun. In the letter mention is made of the house the Bishop had "procured" for the initial group of nuns (ibid.:5). This letter dates after the arrival of the three nuns from Europe (see Clark 1974:3), since it not only mentions them, but includes the names of nuns who later joined the convent (see Garner n.d.:8; copies of the original letter are on file at the CAR-UTSA and the San Antonio Conservation Society).

Most legendary accounts of the early days at the convent would place the first group of nuns living in a rundown adobe hut, or the neglected ruins of a mansion built by a Frenchman, named Jules Poinsard, for his fiancee, who subsequently spurned his love. Documented evidence indicates that neither was the case. In the mortgage transaction mentioned earlier, reference is made by odin to the property on which the convent is being erected (emphasis author's, BDCR Vol. G1:440, 0ct. 12, 1848). This statement refers to the physical act of constructing a building, rather than setting up the convent operation, and is substantially reinforced by a series of letters written to Bishop Odin by F. Giraud over a six-year period. The letters of F. Giraud are contained in an unpublished manuscript, written by Emily Edwards, currently on file with the San Antonio Conservation Society. Letters 1-4, dating from January 15, 1849, to February 23, 1851, contain details concerning progress in the construction of the first building. The first letter (Edwards n.d.:30) is concerned with securing building materials and also details some of the expenses thus far incurred. It also mentions that the work on the limestone foundation is progressing satisfactorily. Since the date of this letter is January 15, 1849, it would not be unreasonable to assume that construction started in late 1848. This letter also refers to the drafts of Guilbeau, Dwyer, and Callaghan (ibid.).

Letters 2-4 (dated March 4, 1849, March 17, 1850, and February 23, 1851, respectively) also concern the progress being made on the convent building (see Edwards n.d.:33, 35-36, 40, respectively). Letter 2 (ibid.:33) mentions the pisé de tierre construction of the walls and their susceptibility to weather unless covered by boards or plaster. Letter 3 (Edwards n.d.:35) includes a progress report and lists construction activities that remained to be done. Letter 4 (ibid.:40) indicates that only work on the north side of the building remained to be completed, and the arrival of the nuns was "eagerly awaited."

There seems to be no doubt that this, the first building constructed by the Ursuline Order, was the building into which the nuns moved upon their arrival September 7 , 1851. This date is recorded in the French nun's letter (Garner n.d.:4). Additional evidence of the first building of the convent is recorded in a series of 
letters written by some of the nuns at the San Antonio convent during the years 1852-1853 (McDowe11, ed., 1977). One letter (McDowe11, ed., 1977:291-293) records the date as the ". . . eve of Exaltation of the Holy Cross, 1851,. . . ." The writer, although not one of the original five nuns, records the arrival of the first group and the conditions that existed:

- . the Sisters arrived at San Antonio, about ten oclock on Saturday night. They drove to the convent, and when they alighted, they were obliged to walk thro' grass a foot and a half high, which trimmed and filled the pathway to the house. Arrived at the halldoor, \& that by moonlight, they saw the hall filled with mortar, rubbish, window blinds, sashes, etc. They stumbled over these, \& ascended the staircase [emphasis author's], \& entered the room now occupied as a Dormitory, \& found there absolutely nothing (ibid.:291-295).

Dated December 24, 1852

Signed Sister M. Patrick Joseph

Garner (n.d.:5) also mentions the room (emphasis author's), which was to be used as the dormitory. He also refers to the spiders and scorpions that greeted the first group of nuns (ibid.).

Subsequent Buildings

This origina1, two-story structure, composed of a limestone foundation and earthpacked (pisé de tierre) walls overlaid with plaster, was only the first of several construction and expansion episodes that were accomplished by the Ursulines at this location. With minor variations, both Clark (1974:7) and Garner (1967) are in agreement on the chronology of subsequent building episodes. Both chronologies are outlined below:

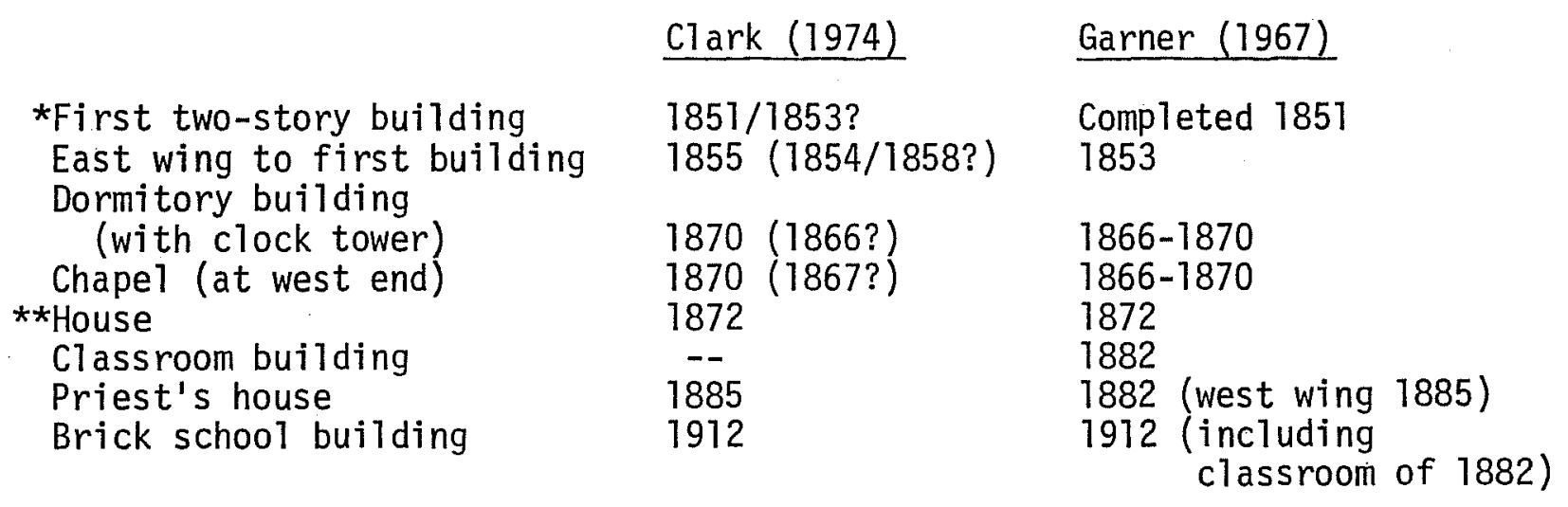

* Known to have been started by 1849 and almost completed upon arrival of the nuns in September 1851.

**Two-story house constructed by John Campbe11--Building 1 (easternmost building) in the study area. 


\section{THE STUDY AREA}

The study area for this project involved a complex of buildings at the southeast corner of the present-day Southwest Craft Center (Fig. 1); these buildings were used for various purposes as dictated by the needs of the Ursulines and subsequent owners. As a result, the buildings are known by various names in historic literature. This may account for some of the confusion that is associated with these structures. For this reason, the study area as a whole is referred to as the Southeast Building Complex, and individual buildings within this complex are referred to as Buildings 1,2, and 3 (Fig. 2). A physical description of each building is provided in the following paragraphs. Since the floors had been removed prior to the study, height measurements are estimated from blueprints prepared by the architectural firm of Ford, Powe11, and Carson Architects and Planners, Inc. (1981). These blueprints are revised drawings dated December 3, 1981.

The study area consists of three primary structures that have been connected to form an irregular "L" (Fig. 2). A passageway or breezeway between two of the structures has also been enclosed and appears to have been incorporated into one of the primary structures. From east to west, the structures are identified as Buildings 1,2 , and 3 , and the breezeway is designated as Section $3 \mathrm{~A}$ because of its apparent association with Building 3. Detailed construction data were prepared by Garner (1969) and sponsored by the Bexar County Historical Survey Commission and the San Antonio Conservation Society in association with the Office of Archaeology and Historical Preservation of the National Park Service. Additional data concerning structural details are included in the project files of this investigation at the CAR-UTSA.

\section{Building 1}

\section{Historical Background}

According to Clark (1974) and Garner (1969) this building was constructed in 1872. Garner's report lists the builder as John Campbel1. This building is depicted in both the 1873 and the 1886 maps of the City of San Antonio (Koch $1873,1886)$.

\section{Exterior Features}

This building is oriented on an east-west axis and is approximately 46.7 feet long and 21 feet wide. The first floor is $101 / 2$ feet in height, and the overa11 height of this building is 27 feet. The exterior walls (ca. 18 inches thick) are constructed of cut limestone blocks set on a somewhat thicker limestone foundation (Fig. 3,a). Door and window lintels are also cut limestone. The gabled roof is metal, but at one time may have been shingled with wooden shingles, as were the roofs of Buildings 2 and 3. The 1904 Sanborn map (copies on file at Trinity University Archives and the (AR-UTSA) depicts a single story wooden structure connecting the east side of this building to another stone building farther to the east. Both of these were probably removed when a bridge was constructed across the San Antonio River, and when St. Mary's Street was extended 


\section{SOUTHEAST BUILDING COMPLEX}

OLD URSULINE ACADEMY

SAN ANTONIO, TEXAS

1982

$\square$ Test Pit 5

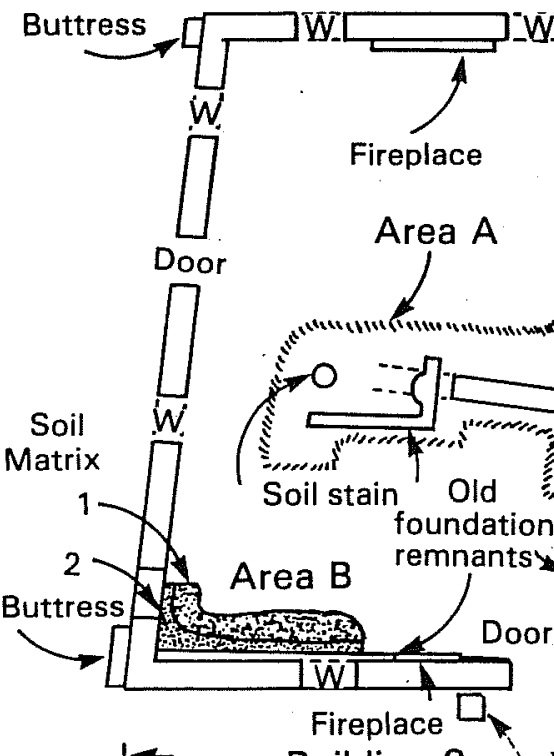

$1 \leftarrow \quad$ Building 3
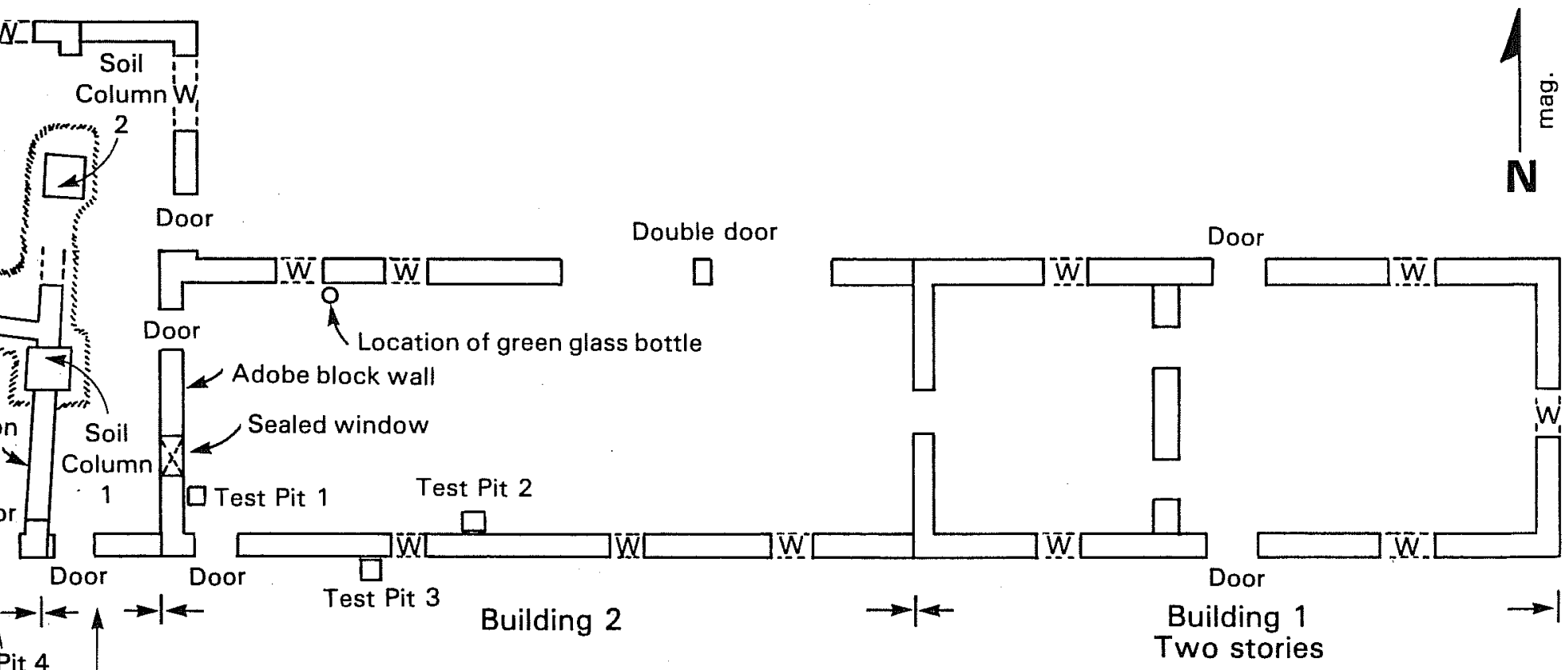

Test Pit 4

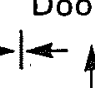

oor

Section $3 A$ $\square \overline{\mathrm{w}} \square \overline{\mathrm{w}}$

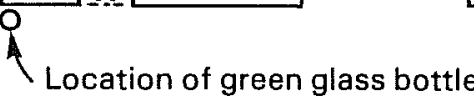

Door

Adobe block wall

\section{ow}

Test Pit 2

Test Pit 1
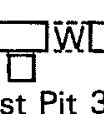

-

Building 2

Two stories

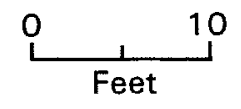

Figure 2. Old Ursuline Academy, Southeast Building Complex. Ground plan indicating locations of excavations. 


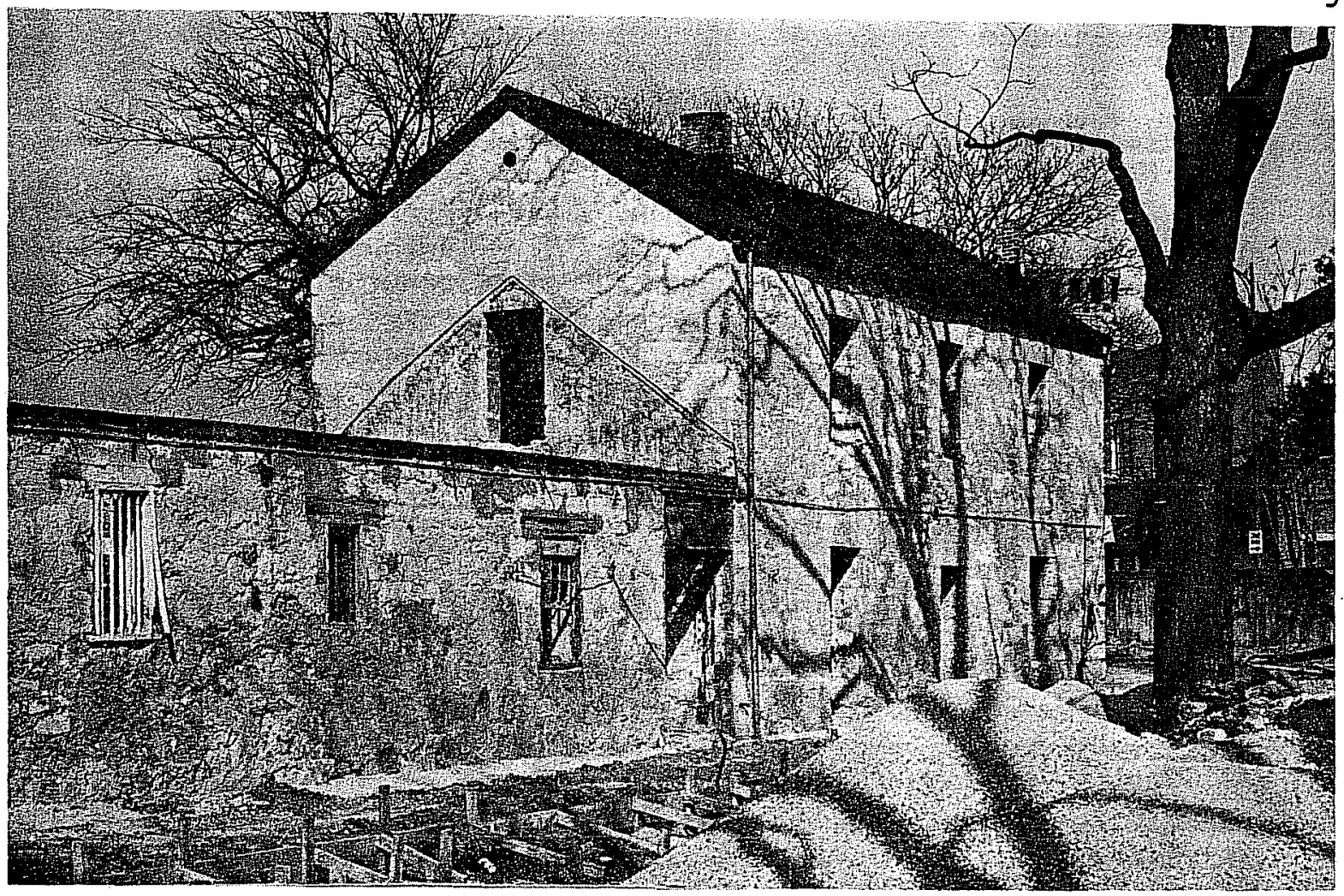

a

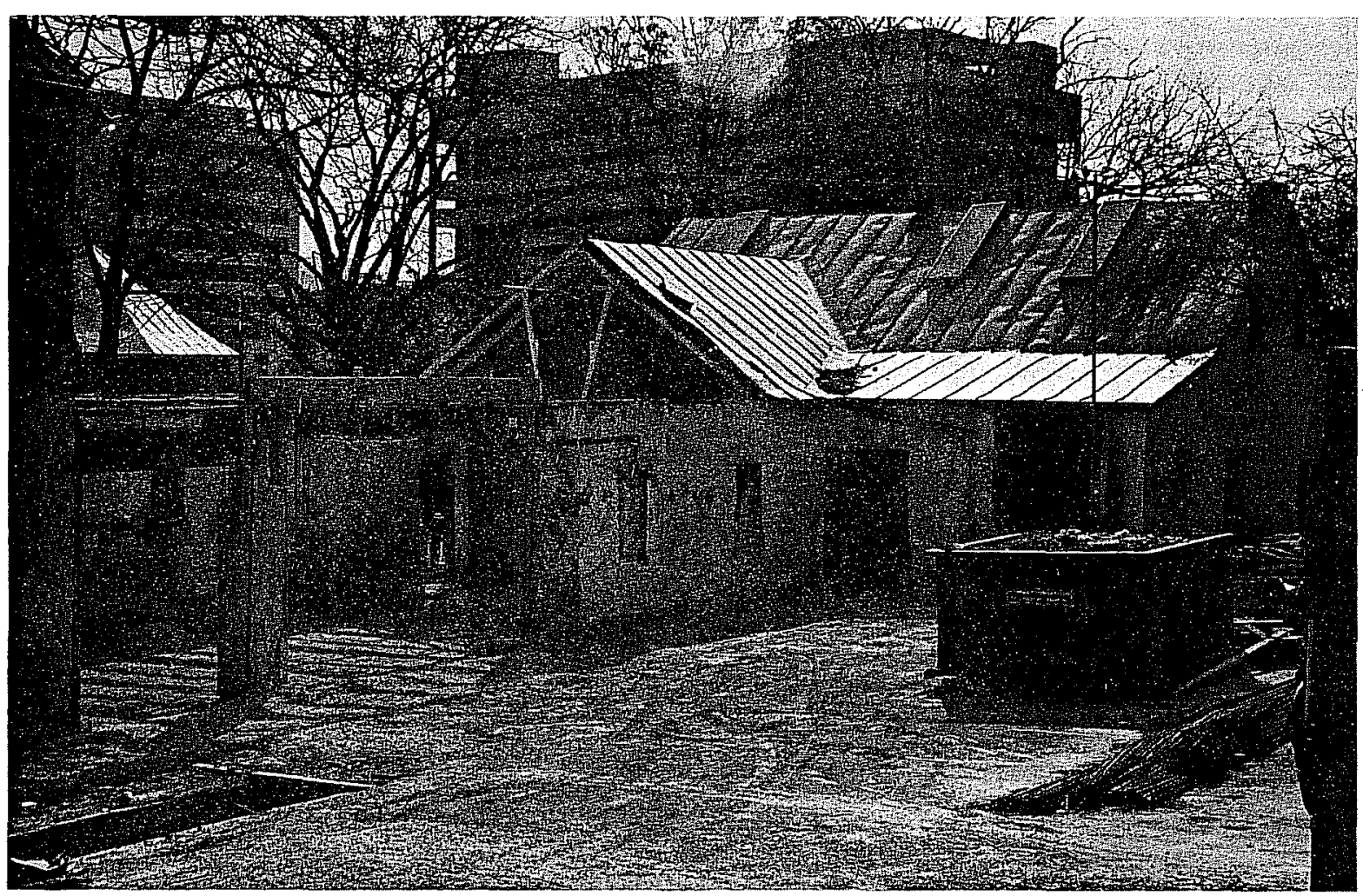

b

Figure 3. Old Ursuline Academy, Views of Southeast Building Complex. $a$, south side of Buildings 1 and 2 , looking northeast; $b$, north side of Buildings 2 and 3 , looking southwest. 
to the north in 1915 (Clark 1974:35). The March 1979, Newsletter of the Southwest Craft Center depicts a covered walkway extending across the north face of Building 1. The north and south facades have three openings on each floor with the center opening of each wall of the first floor utilized as a doorway. The north facade is depicted in a photograph accompanying the article. A single opening is present on each floor of the east and west sides of the building with the first floor openings apparently used as doorways connecting the building to adjacent structures.

Detailed measurements concerning window and door dimensions and placements were recorded, and photographic records of all exterior faces were made (on file; CAR-UTSA).

\section{Interior Features}

Only one interior wall, one story in height, was present at the time of this survey. This first floor wall is also constructed of cut limestone blocks on a wider limestone foundation similar to the exterior walls and was apparently erected as part of the original design. This wa11, located approximately 26 feet from the east wa11, has two doorways connecting the two rooms. No first floor materials were present. When we arrived, these had been removed and replaced by a gravel fill in preparation for a new floor. Garner (1969:3) records the first floor as one of portland cement construction. Presumably, this material was a later modification. A fireplace, subsequently filled in, is located on the east side of the interior wall.

The second story floor is wooden tongue and groove construction. Evidence of wooden interior walls fastened to the limestone walls is present, but all interior walls have been removed. The stairwell also has been removed. Garner (1969:3) describes the stairwell as one of ". . . turned ballusters and newel of plain Victorian design." Detailed measurements and photographic documentation of the interior of this building were recorded (on file; CAR-UTSA).

\section{Building 2}

\section{Historic Background}

No documentation concerning the construction of this building by the Ursulines was located during this study. The 1904 Sanborn map and the Green (n.d.) map refer to this building as the "Music Room." Clark (1974:Fig. 3) designates this as the "Carriage House." The materials and construction techniques associated with this structure suggest an early construction date with several subsequent modifications. This building is also depicted in the "Bird's Eye View" maps of San Antonio (Koch 1873, 1886).

\section{Exteriar Features}

Building 2, also oriented on an east-west axis, is 54.9 feet in length and 21 feet in width, matching the width of Building 1. The walls are limestone 
rubble set on larger limestone foundation stones (Fig. 3). The east wall of this building is actually the west wall of Building 1 . The 1imestone rubble material of the other walls varies in height from ca. three to seven feet. Within this rubble level evidence of remodeling and/or repair is represented by a change in mortar used in the wall construction. At the lower levels, the mortar is brownish gray in color. The higher levels contain a pale pinkish mortar. This changeover was not observed at any specific elevation, but rather varied in height from wall to wall and from place to place along any one wall. Milled lumber embedded in the limestone rubble level was also noted, as were window casements that varied in style. Capping the limestone rubble level was a pale pinkish mortar similar to that used on the upper portions of the rubble layer. These walls were capped by wooden planks, ca. eight inches wide, to which the rafters were attached. The south wall exterior was not overlaid with a plaster coat, but patches of mortar were noted, indicating repair activities had taken place. The exterior of the north wall was overlaid with plaster and, in recent times, painted white. Episodes of earlier plastering and painting were noted beneath the outer layer of plaster. Examination of the south wall exterior revealed a limestone rubble wall supported by a foundation of larger limestone rocks. The rubble construction varied in height from two to four feet and was topped by soft, irregular-shaped caliche blocks that were packed with earth. The caliche block layer extended in places to a height of seven feet. Crude adobe blocks, irregular in shape and also packed with earth overlaid the caliche block layer. These adobe blocks continued to a height of 18 feet forming the roof gable. In the northwest corner of this wall a doorway, three feet wide, is framed by cut limestone blocks. As on the south wall exterior, no plaster finish was observed. This wall also had a window, which has subsequently been filled in and plastered over on the inside.

Three quarters of the roof had been removed, but the remaining section was examined. Spanning the rafters was a layer of rip-cut boards approximately one to one and one half inches thick and varying widely in width. Garner (1969:1-2) describes some of these boards as still retaining the bark of the tree from which they were cut. These boards are attached to the rafters with square cut nails. These nails were also used to attach the rafters to the wooden planks, which capped the walls. At one time this building was covered by a wooden shingle roof (also attached with square cut nails), but now the roof is a metal sheeting type similar to the roof of Building 1 .

\section{Interior Features}

The floor had been removed prior to this study and had been replaced by a gravel base in preparation for a new floor. Relevant height information was obtained by examining the bases of the interior walls, which still retained flooring materials. Examination of the interior walls revealed repair and/or remodeling' episodes, which closely paralleled data from the outside wall surfaces. At a height of approximately seven to eight feet a setback, or narrowing of the wall thickness, of the north and south walls was noted. The wall thickness decreased from 18 inches to approximately 14 inches resulting in a slight ledge along these walls. Subsequent plastering and painting activities resulted in giving this setback a gentle sloping appearance, rather than an abrupt ledge. The narrower portions of the walis were also composed of caliche blocks set in a pinkish mortar. These blocks were approximately one foot high, resulting in 
an overal1 wal1 height of nine to ten feet. It appears that the rafters were left exposed as no evidence of a ceiling was noted.

Additional construction details concerning this building are on file at the CAR-UTSA.

\section{Archaeological Activities}

Test pits were placed at three locations with respect to this building and are discussed in more detail in the EXCAVATIONS section of this report. A photographic record of significant interior and exterior characteristics was made and is on file at the CAR.

\section{Building 3}

\section{Historic Background}

This building is oriented along a north-south axis and is approximately 39 feet long and 25.6 feet wide. It is approximately 20.5 feet in height (Ford, Powe11, and Carson Architects and Planners, Inc. 1981). The 1904 Sanborn map 1ists this as the kitchen, as does the Green (n.d.) map. Clark (1974) identifies this building as the laundry, and Garner (1969) includes this building, as well as Buildings 1 and 2, as the laundry. More recently it has housed two ceramic kilns (Mrs. Donald Saunders, personal communication). The 1873 "Bird's Eye View" map depicts a building which may be this structure, but the perspective is difficult to determine. The 1886 "Bird's Eye View" map depicts a building of similar appearance in approximately the right location, but this structure appears to be too far to the north. This discrepancy is addressed in more detail in the INTERPRETATIONS section of this report.

\section{Exterior Features}

This building is not squared, but rather forms a rhombus with the north-south running walls offset slightly to the east (Fig. 2). The south wall of this structure is aligned with the south wall of Buildings 1 and 2, which results in the buildings forming a uniform face across the south (Fig. 3,b). Garner (1969) mentions a smal1 "add-on" projecting from the south wall (see also Clark 1974:Fig. 3), but this feature had been removed at the time of this survey. The 1904 Sanborn map depicts one story, wood frame porches along the west and north walls, as well as the northern portion of the east wall. These also were no longer in place. The northern portion of this building extends 17 feet farther north than Buildings 1 and 2. Two buttresses project westward from the west wall. The southwest corner buttress is ca. 48 inches (north-south) by 10 inches (east-west), and the northwest corner buttress measures 24 inches (north-south) by 10 inches (east-west). The east wall of this structure is no longer present, it was apparently removed when Section $3 \mathrm{~A}$ (once an open area between Buildings 2 and 3 ) was walled in and incorporated as part of Building 3. However, the original east wall location is represented by interior foundation remnants at the southeast and northeast corners, the existing roof line, and two wooden support posts that were apparently set in place when this 
wall was removed. The foundation remnants and soil columns supporting these posts are discussed in the EXCAVATIONS section of this report.

The exterior walls are constructed of cut limestone block and mortar set on irregular 1 imestone boulders. These walls are ca. 18 inches thick. The exterior wall on the south is of natural stone; the north and west walls have been finished with plaster. A white plaster finish was also noted on the east wall of Section 3A where this wall joins the north wall of Building 2. The exterior walls extend above the ground surface to a height of ca. 10 to 11 feet with the top 12 to 14 inches composed of soft, square cut caliche blocks similar to those used in Building 2.

The roof is gabled and covered with metal roofing. Examination of the interior revealed the rafters had been overlaid with milled lumber and at one time was finished with wooden shingles. The shingles and milled lumber were attached with square cut nails.

\section{Interior Features}

The floor had been removed and the ground beneath leveled with gravel fill at the time of this survey. Two columns of earth surrounded and supported the vertical support posts of the east wall and were left intact for stratigraphic examination. Filled in fireplaces were located on both the south and north walls. The fireplace on the north wall is centered on the wall and is discussed in the INTERPRETATIONS section of this report. The rafters were exposed in this building, and no evidence of a suspended ceiling was noted. Setbacks similar to the interior walls of Building 2 were noted in this building. Above these setbacks caliche blocks were used, while below this level the primary material was cut limestone blocks. Occasional caliche blocks were noted infrequently in the limestone level and may indicate one or more episodes of repair or remodeling. What appeared to be a filled-in doorway was observed in the west wall at the southern end. Examination of the existing doorways and windows revealed that wooden door and window casements were attached to the limestone frame with wooden dowels or pegs. See Figure 2 for door and window locations of this building at the time of this study.

\section{Archaeological Activities}

Detailed measurements were taken of this building, and photographic sequences of interior and exterior features were made (on file; CAR-UTSA). Profile measurements and drawings of the two support columns were made and photographed (Figs. 4 and 5). Excavations associated with this building included two test pits, one major excavation area (Area A), and one minor excavation area (Area B). These activities are discussed in the EXCAVATIONS section of this report.

\section{Section $3 A$}

Section $3 A$ is a narrow, trapezoidal area between Buildings 2 and 3 that has been enclosed and incorporated into Building 3 (Fig. 2). Section $3 A$ measures 39 feet in length. Interior width measurements are seven feet at the north end 


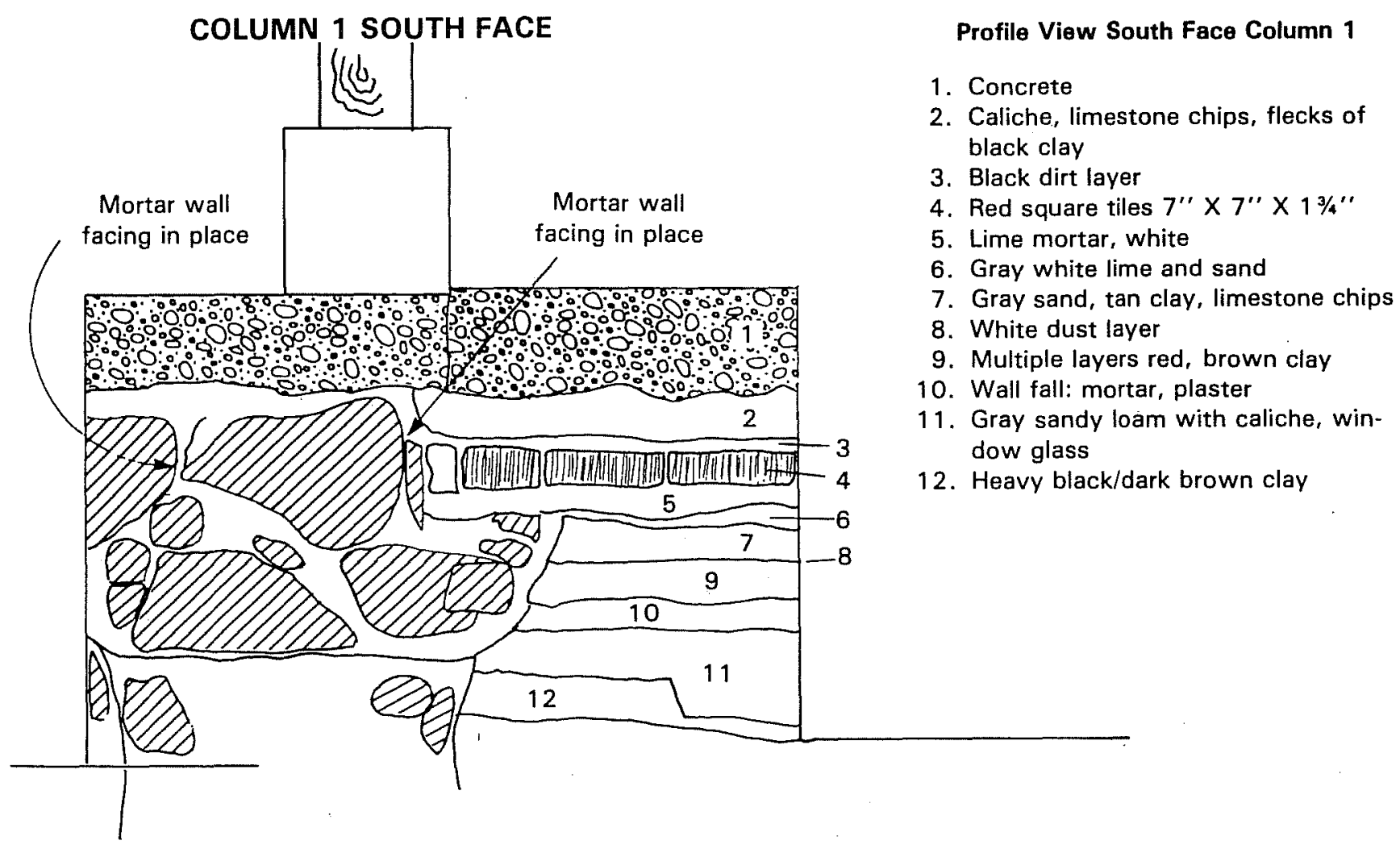

COLUMN 2 SOUTH FACE

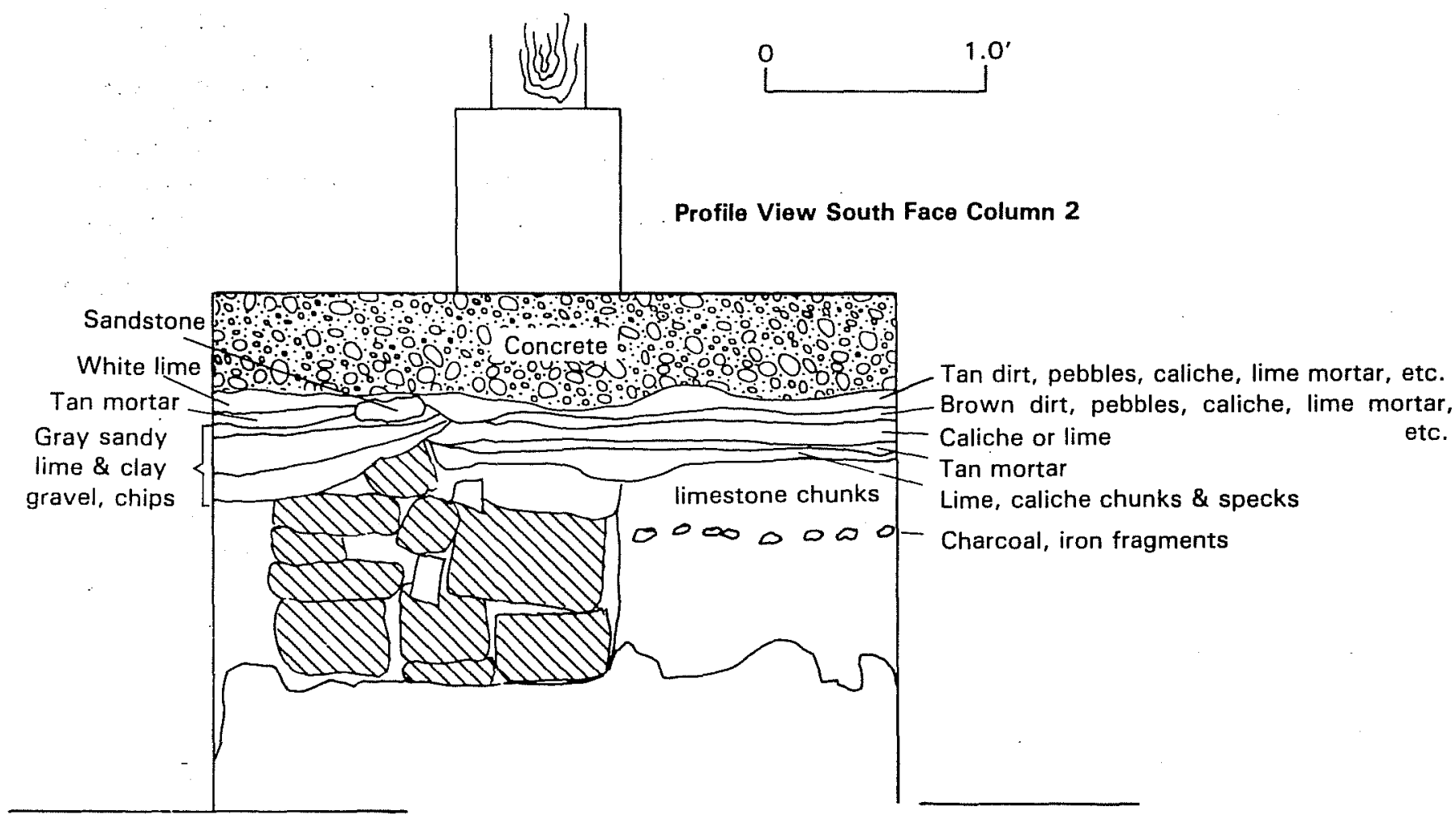

Figure 4. Old Ursuline Academy, Southeast Building Complex, Building 3, Area A. South face profiles of Columns 1 and 2. 


\section{EAST FACE COLUMN 1}

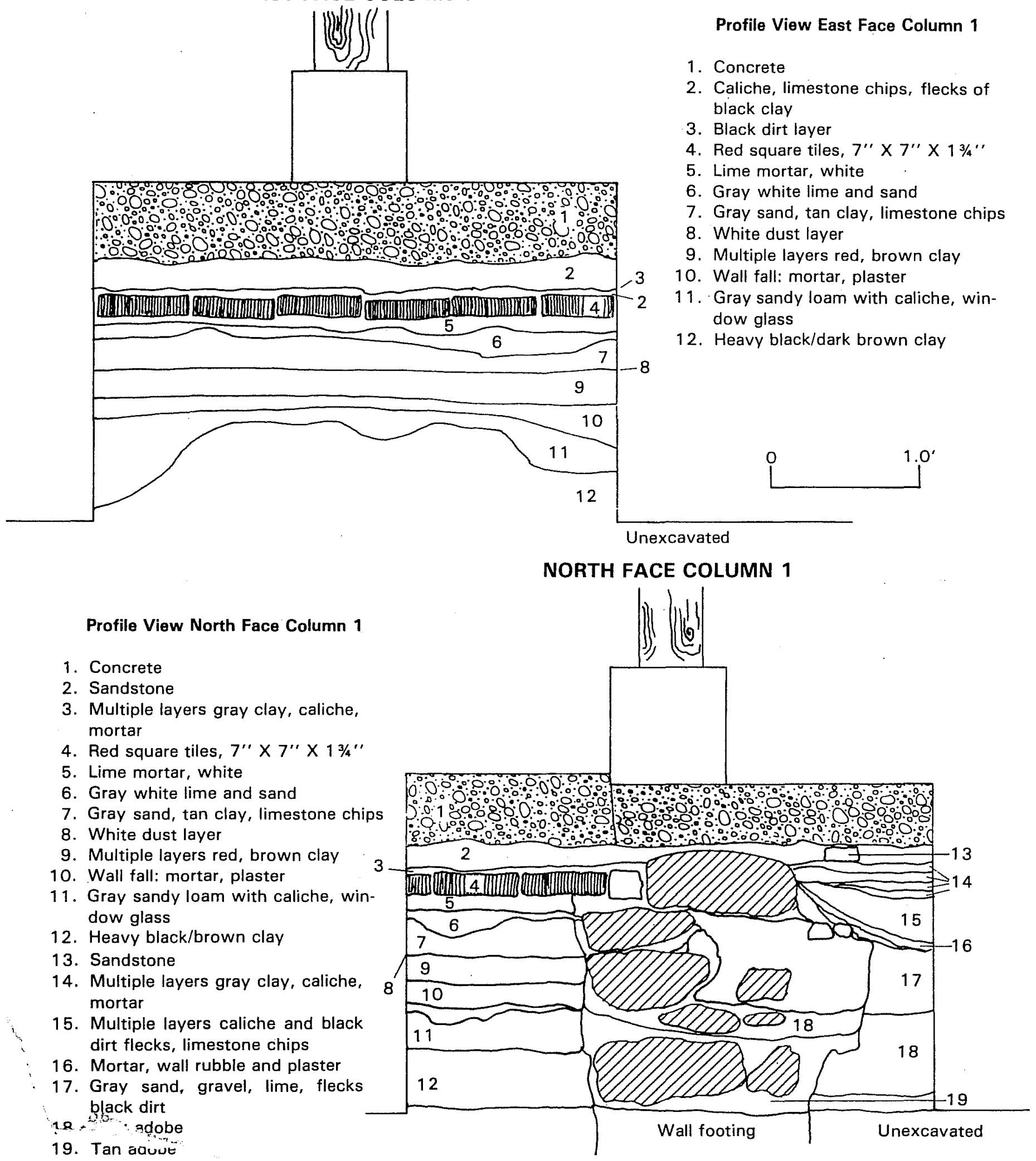

19. Tan aquete

Figure 5. old Ursuline Academy, Southeast Building Complex, Building 3, Area A. East and north face profiles of Column 1. 
and nine feet, two inches at the south end. The roof for the southern portion of this section is an extension of the roof of Building 2, which has been extended to join the roof of Building 3. The northern portion of this section's roof is a sloped section, which declines to the east to a height of six and one half to seven feet. This roof section is also covered with metal roofing.

The south wall of this enclosure is butt jointed to both the west wall of Building 2 and what was once the east wall of Building 3 . The south wall is constructed of limestone rubble and mortar to a height of five to six feet, topped with soft, cut caliche blocks that continue to a height to line up with the south wall of Building 2. The southern portion of the east wall of this section is formed by the west wall of Building 2, which was not plastered. The remaining portion of the east wall and the north wall are of limestone rubble and mortar construction overlaid with plaster on both the interior and exterior surfaces. The northern portion of the east wa11 apparently had been repaired, at times, since both brick and cinder block materials were noted in spots.

Detailed measurements were recorded and significant features of this section were photographed (on file; CAR-UTSA).

\section{EXCAVATIONS}

A total of five test pits (designated Units 1-5) and two block excavation areas (designated Areas A and B) was excavated during the field work phase of this study. These excavations are plotted in Figure 2. In addition, two soil matrix columns supporting vertical posts along the east side of Building 3 were examined. The results of these activities are outlined in the following paragraphs.

\section{Column Profiles}

Two soil matrix columns located in Building 3 were examined. Column 1 (Fig. 2) extended 22 inches above the present ground surface. Another four inches of soil were removed from the area surrounding this column, resulting in an overall height of 26 inches from the excavated floor. The surfaces of column 1 were cleaned and shaved, resulting in four uniform faces measuring approximately three and one half feet across. Column 2 was similarly cleaned and squared, resulting in four uniform faces that measured approximately four and one half feet across. Stratigraphic profile drawings were made of significant faces, and these faces were photographed. Examination of the faces of Column 1 revealed previous flooring and/or construction episodes, represented by distinct layers of mortar, rubble, adobe, and red tiles. Profile drawings of the east face and the south face of column 1 are presented in Figures 4 and 5 . A wall footing, presumably associated with the absent east wall of Building 3 is visible in both the north and south profiles (Figs. 4 and 5).

Column 2 was recorded in similar fashion except no profile drawings were m: te for the north and west faces. Column 2 south face profile is presento.,... rigure 4. The height of Column 2 was ca. 24 inches above the existing ground surface, and the soil matrix around the base of this column was excavated to a depth of four inches, resulting in a column height of 28 inches above the excavated floor. 
A wall footing was noted in this column; this may be associated with the absent east wall of Building 3. A comparison of the south face profile of Column 2 and north face profile of Column 1 indicates the wall footings are of similar depths when measured from the tops of their respective columns. Significantly fewer strata were noted in Column 2 than in Column 1 . Elevation readings were made along several points on the top surface of the concrete layer capping each column. Column 1 elevations ranged from 2.94-3.00 feet below the primary datum established for this project, while the readings for the surface of column 2 ranged from 2.98-2.99 feet below the datum, indicating that a fairly level floor surface existed. Further discussion of the soil columns is presented in the INTERPRETATIONS section.

\section{Test Pits in Building 2}

Three test pits were placed adjacent to the walls of Building 2 (Fig. 2). Unit 1 was located adjacent to the interior side of the west wall; Unit 2 was located adjacent to the interior side of the south wall; and Unit 3 was located along the south wall exterior.

Unit 1 measured $21 / 2$ feet by $21 / 2$ feet and was excavated to a depth of 20 inches following the removal of four to six inches of gravel overburden, including a layer of coal dust, coal chunks, and window glass fragments. As mentioned in an earlier section, this wall contained a closed-in window casement. At a depth of 18 inches the soil graded into a tannish-colored caliche soil upon which the wall foundation stones rested. No construction materials were noted below this level. A profile view of the north face of Unit 1 is presented in Figure 6.

Unit 2 measured 18 by 15 inches and was excavated to the base of the interior foundation for the south wall, a depth of 15 inches. The upper 10 inches of the foundation were mixed with a yellowish, sandy adobe, while the bottom five inches were mixed with a tannish brown adobe. A thin layer of tan-colored plaster was also noticed in the upper two inches. Beneath these adobe and plaster levels the soil is a dark brown clay. A profile of the west face of this unit is presented in Figure 6.

Unit 3 measured 12 by 15 inches and was excavated to the base of the exterior side of the south wal1, a depth of approximately 15 inches. The foundation characteristics and the matrix levels were consistent with those of Unit 2 . No profile drawings or photographs were made.

Test Pits in Building 3

Two test pits were dug in association with Building 3 . Unit 4 was adjacent to the south wall exterior, and Unit 5 was five feet north of the north wall and aligned with the west wall (Fig. 2).

Unit 4 measured 12 by 15 inches and was adjacent to the south wall exterior of Building 3. This unit was excavated to a depth of 16 inches to determine the base of the wall foundation. No significant observations concerning the stratigraphy associated with this unit were noted. No profile drawings or photographs were made. 

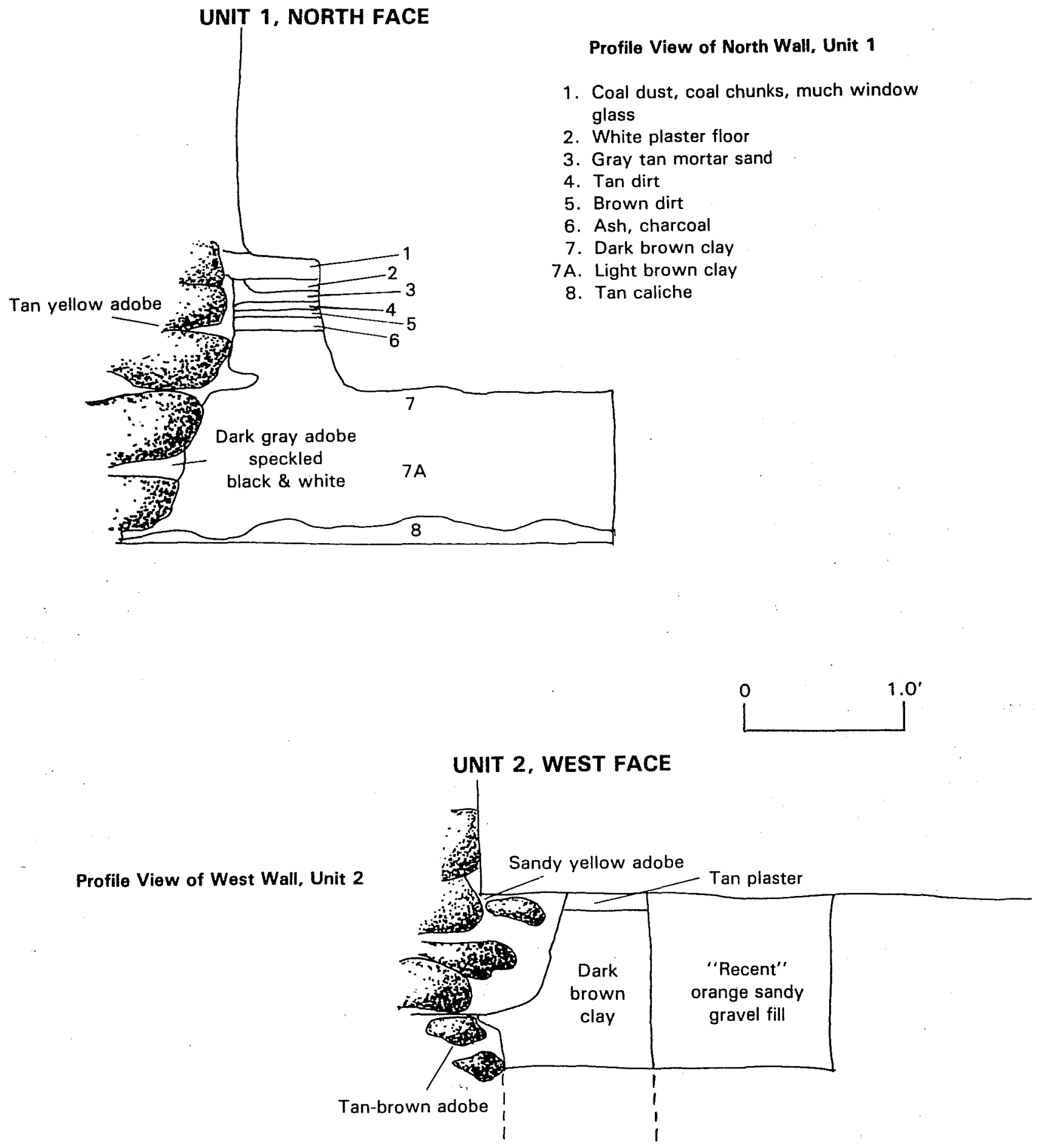

Figure 6. Old Ursuline Academy, Southeast Building Complex, Building 2. Profiles of Test Units 1 and 2. 
Unit 5 measured 24 by 18 inches and was excavated to a depth of 20 inches where level limestone blocks were encountered. Excavations continued to a depth of 28 to 30 inches in order to determine the base of these blocks. The blocks were square in shape, approximately four to six inches thick, five to eight inches wide, and 10 to 12 inches long. The position of the blocks was in alignment with the west wall of Building 3 approximately five feet north of the north wa11. It is uncertain whether these blocks can be associated with a structure, which has been removed, or whether they represent construction debris associated with the construction of Building 3. No photographs were taken of this unit, nor were profile drawings made.

\section{Block Excavations}

Two block excavation areas. were opened during this project. Area $A$ was associated with Columns 1 and 2 (Building 3) and the wall footings, which were exposed during the examination of these columns. Area $B$ was located along the interior of the south wall of Building 3. Both areas were irregular in form since these areas were opened with reference to the features they exhibited. The depth of these areas ranged from two to eight inches, again depending on the feature characteristics of each area. Areas A and B are depicted in Figure 2.

Area $A$ was an expansion of the column cleaning activities associated with Columns 1 and 2. During these activities, two buried wall footings were exposed. One footing of limestone cobble construction projected northward from the Column 1 pedestal ca. two feet eight inches at which point it terminated. It was in alignment with the wall footings exposed in Columns 1 and 2 and appears to be associated with the same wall. This footing was joined to an east-west footing of similar construction. The juncture of the two footings was 12 inches north of the Column 1 pedestal. The second wall footing extended westward from the first wall footing a distance of seven feet ten inches, at which point it also terminated. Both footings were uniform in width, approximately 20 inches. This second footing was bisected by one leg of an L-shaped stain exposed in the floor of the structure. This stain was four feet four inches long on the north-south leg and seven feet one inch long on the east-west leg. The stain was uniform in width; generally 7 1/2 inches wide, and displayed distinct edges which differed sharply from the surrounding soil matrix at the same level. The position of this stain is depicted in Figure 2.

A second stain, circular in form with a diameter of 15 inches, was also exposed. This stain. was two feet four inches north of the west end of the first stain (Fig. 2). This second stain was seven feet two inches from the west wall of Building 3, and the first stain was seven feet ten inches from the west wall.

Area B was placed at the southwest corner of Building 3 . The area extended northward along the west wall interior six feet and eastward along the south wall interior 19 feet six inches, terminating at the southeast entrance to Building 3. This area was irregular in width (Fig. 2) and was excavated to depths varying from two inches to five inches, exposing an abrupt change in soil color and texture. Associated with the building foundation, the soil was dark brown in color and composed of a compact clayey soil similar to the soil in Level 12 of the east face profile of Column 1 (Fig. 5). Within the boundaries of this dark brown soil, a second soil matrix was encountered, a 
compacted clayey, caliche type that ranged in color from light gray to grayish tan. This second matrix was compatible with the soil noted in other excavations in this building.

\section{THE ARTIFACTS}

Artifact recovery during this project was minimal. This was due, at least in part, to the construction and remodeling activities, which had been carried out prior to this study.

Artifacts from Disturbed Provenience:

5 chert flakes/chips

8 unidentified bone fragments ( 1 with three butchering marks)

1 tooth (bovid)*

2 complete bones (rodentia)*

1 window glass fragment

2 green bottle glass fragments

1 hand-painted whiteware jar fragment (base)

1 cowrie she11, annular (ringed)

* Based on CAR comparative collections

Provenienced Artifacts:

1 brown chert biface fragment (Column 1 Zone 12 east face)

1 blue transfer print whiteware fragment (Column 1 Zone 11 east face)

1 red hand-painted whiteware fragment (Column 1 Zone 11 east face)

1 green giass bottle (north wall of Building 2)

The transfer print technique was first introduced in the 18th century and continued in use into the 20th century (Gerstle, Kelly, and Assad 1978:285). This time span is too long to provide useful information in dating. However, hand-painted whiteware was widely used throughout Texas by 1840 and continued in use during the 1850s (Fox, Bass, and Hester 1976:55). This period is better defined than that for the transfer print but it, too, should be considered more general than absolute.

Examination of the green glass bottle found in situ revealed characteristics that permit a more precise age estimation. This bottle was found embedded in the north wall of Building 2 (see Fig. 2) at the base of a milled wood post, which had been set into the limestone rubble wal1. The bottle was approximately two inches above the latest floor level (although this floor had been removed, remnants were still visible in the wall profile). The bottle has an improved pontil, a sheared lip with a laid-on ring, and no mold seams. The dimensions of the bottle are as follows: seven and $7 / 8$ inches tall, two and $5 / 16$ inches wide at the base, 15/16 inches at neck width, 5/8 inches at neck opening, an eight ounce capacity, and the deepest recess of the kickup one and $9 / 16$ inches. According to McKearin (1948:112-114), the 1aid-on ring technique was most popular from 1840-1860. Newmann (1970:71-75) assigns a date of 1840-1880 for the improved pontil. These time periods should not be viewed as absolute dates, but rather, as dates within which these characteristics are most common. These dates do 
conform to the period in which significant repair and/or modification activities are believed to have occurred in the Southeast Building Complex. Illustrations of similar bottles are contained in Fox and Livingston (1979:54, Fig. $31, a)$ and Gerstle, Kelly, and Assad (1978:292, Fig. 71,c).

\section{INTERPRETATIONS}

Although specific documentation concerning the construction of the buildings in the Southeast Building Complex was not available, several features concerning these buildings can be combined to offer a possible construction sequence model for this complex. This model should be considered as speculative and subject to revision as additional data become available in the future.

The presence of buildings in, or near, the study area is supported by two letters written in 1852 and 1853 by nuns who resided at the convent. One letter, dated October 1852, refers to ". . . a kitchen, storeroom, fow 1 house, \& back apartments . . ." located east of, and separate from the main convent building (McDowe11, ed., 1977:232). Another letter, dated December 16, 1852, mentions a carpenter's shop behind the kitchen (ibid.:265). The relationship of these structures to the present-day structures are discussed in the following paragraphs.

\section{Building 1}

This two-story structure has been assigned a construction date of 1872 by both Garner and Clark (see page 6). Garner 1ists the builder as John Campbel1. A copy of the construction contract, dated August 3, 1872, was obtained from Sister Euphrasia of the Ursulines (Ursuline Academy Files) during the preparation of this report. The contract includes significant details concerning construction techniques and materials of that time period. A reproduction of this contract is provided in the Appendix of this report. This building is identified by Clark (1974:7) as part of the carriage house and groundkeeper's house. Edwards (1981:66) describes this building as the music building, which had a carriage house and a laundry east of this structure (this would place these last two buildings outside of the study area, presumably demolished when St. Mary's Street was extended across the San Antonio River in 1915 [Clark 1974:35]). As early as 1904, this building had been identified as the laundry (1904 Sanborn map). This latter designation may be due to the fact that this building housed a boiler at the time the present remodeling project started (Mrs. Donald Saunders, personal communication). Part of the laundry operation may have been moved to this building during the St. Mary's Street extension. Building 1 has probably continued to the present day with comparatively minor modifications.

\section{Building 2}

Building 2 has been identified by Clark (1974:7) as the carriage house. Green (n.d.) also identifies this structure as the carriage house, but Edwards (1981: 47) refers to a workshop in this area. This may have been Building 2 . 
This building has apparently undergone several episodes of remodeling and/or repair. These episodes are represented by: (a) mismatched window/door casements; (b) walls constructed/repaired with adobe block, limestone rubble, caliche block, and cut limestone blocks; (c) different mortar types used in upper and lower wall elevations; and (d) wooden shingle roof overlaid with metal roofing.

Square-cut nails were used in joining the rafters to the top plates of the walls. Although wire nails were manufactured in the 1850s, cut nails remained more popular than wire nails until about 1879 (Fontana 1965:89). A comparison of the nails embedded in the rafter construction with the description provided by Fontana and Greenleaf (1962:54) suggests the nails associated with Building 2 were manufactured between 1830 and ca. 1890.

Rough-cut lumber as well as milled lumber is also present in this building. No origin for these materials has been determined, but milled lumber was apparently produced locally by a planing mill in San Antonio by 1851 (Steinfeldt 1978: 66).

This building is apparently the oldest structure in the complex. This determination is based on the adobe structure of the west wall which had been repaired in places with cut limestone block. The limestone rubble walls also suggest an early construction date. Its use, in part, as a storeroom is evidenced by the remains of what appears to have once been a coal pile in the southwest corner of the building. The two double-doors set into the north wall suggest it also functioned as a carriage house or garage structure. It appears that this building has always been used as an outbuilding.

\section{Building 3}

This structure has been identified by $\mathrm{Clark}(1974: 9)$ as the laundry. This identification is probably due to the building having a boiler housed in a small cinder block addition to the south wall (not present during this project) and the presence of ironing boards in the building as late as 1971 (Mrs. Donald Saunders, personal communication). It may have been used as a laundry in recent times, but, according to Green (n.d.), this structure was the kitchen. The 1904 Sanborn map also identifies this structure as the kitchen.

The present building does not seem to be the original structure on this site. Foundation remnants of an earlier structure were uncovered during this project (Fig. 2). This earlier foundation is also evident in the south face profile of Column 1. A second wall foundation in this profile appears to be associated with the east wall of the existing structure, which has since been removed. The original structure was somewhat smaller than the present structure, but it appears that the south, east, and west wall lines of the earlier structure were utilized in the construction of the present-day building (Fig. 3,b). Examination of the south face profile of Column 2 reveals a single wall foundation, believed to be associated with the once existing east wall of the present structure. A comparison of the south face profiles of both Columns 1 and 2. (Fig. 4) reveals multiple episodes of construction and/or modification occurred in the area of Column 1 (the southern part of Building 3), and a noticeable absence of such episodes in Column 2. These factors would suggest that a smaller structure was 
razed in order to build a larger structure, and the second construction episode utilized existing wall foundations where possible. This may, or may not, be linked to the present day absence of a structure, which existed further north of Building 3. This structure is depicted in a photograph contained in Clark's (1974:6, Fig. 2,b) report. This photograph is also on file as part of the Gentilz Photograph Collection, Daughters of the Republic of Texas Library. In addition to being too far north to be Building 3, this structure has a chimney located at the north end of the west wall. Building 3 has fireplaces located on the north wall and the south wall, but none on the west wall. Repairs, using cut caliche blocks, have been made to the south wall, especially at the southwest corner. The height of the west wall has also been extended with the addition of cut caliche blocks.

Based on available data, it seems this building served as both a kitchen and a laundry. The change in function may have occurred as a result of the extension of St. Mary's Street when the Taundry identified by Edwards was removed.

\section{Section $3 A$}

This structure is included by Clark (1974:9) as part of the laundry. The 1904 Sanborn map depicts this as a building of single story, wooden construction. The east face profile of Column 1 (Fig. 5) reveals that this hall at one time had a red tile floor. Since the west face profile of this column does not exhibit these tiles, this suggests that the red tile floor was present before this area was incorporated into Building 3 . The rubble wall enclosing the south side of this structure is butt jointed to both Building 2 and Building 3 , indicating this was built some time after the construction of Buildings 2 and 3 . The height of this wall has also been extended with concrete blocks. According to Edwards (1981:66), a gallery (open porch area?) was associated with this kitchen. This may have been the gallery to which she referred and was subsequently enclosed to form the wooden structure noted in the 1904 Sanborn map. The latest modification to this area is probably that which incorporated it into Building 3 by removing the east wall of Building 3 and closing in the north and south sides of Section $3 A$.

\section{CONCLUSIONS}

An examination of the assembled data suggests two major renovation episodes occurred in the Southeast Building Complex. It appears that these efforts were accomplished in order to permit a more efficient use of the existing structures and improve the aesthetic appearance of the complex, or possibly a combination of both. The first episode is suggested by the following details:

1. The removal of a structure which interfered with the view of the east facade of the pise de tierre building.

2. The removal of a small structure that was subsequently replaced by Building 3.

3. The use of cut caliche blocks to raise the building heights of Buildings 2 and 3 and Section $3 A$.

4. The slight offset of the south wall of Building 3 on its foundation, permitting the south wall of Building 3 to be aligned with the south walls of Buildings 1 and 2, presenting a uniform facade fronting the river. 
No specific date can be assigned to these activities based on the existing data, but these activities were completed prior to the arrival of Emily Edwards in 1898 (Fig. 1). It is suggested that these activities occurred in conjunction with, and as an adjunct to, the construction activities accomplished during the years following the Civil War. From the end of the Civil War until 1885, several buildings were constructed on the convent proper. This period was one of significant expansion for the convent. Building 1 was also built during this period, and it would seem reasonable that a large scale renovation of the buildings adjacent to Building 1 was included during this construction period. At least one large scale effort is suggested by the use of caliche blocks in Buildings 2 and 3 and in Section $3 A$.

A triangular, hand-carved stone block placed over a doorway in the west wall of Building 3 has been identified as being the cornerstone for the pisé de tierre building, since the west side was regarded as the "front" of the convent, facing Augusta Street (Edwards 1981:3; McDowe11, ed., 1977:231). Since the chapel was constructed ca. 1870, this would place the construction of Building 3 sometime after this date and possibly at a date compatible with the construction of Building 1 in 1872 .

The second major episode which concerns the Southeast Building Complex may provide insight into the apparent confusion concerning the functions of these buildings. In 1912 the construction of a large three-story building was completed on the convent campus, providing much needed classroom space as well as space for other activities. Although Garner (1967) and Clark (1974) both assign the date of 1912 to this building, Garner (n.d.:11) also assigns a date of 1909 to this building. This discrepancy may simply reflect dates of building dedication and building use. However, a parcel of land was sold by the convent to the city for the purpose of extending Navarro Street across the San Antonio River (BCDR 313:149-150, May 25, 1909). This sale included the property upon which the original laundry, as well as the garden and cemetery, was located (Fig. 1). This sale could have required relocating the laundry to another building.

According to Sister Euphrasia, upon her arrival at the convent in 1940, the kitchen was located in the basement of the dormitory building at the northeast end directly below a pantry or food service area that is now the kitchen for the Copper Kitchen restaurant operated by the Southwest Craft Center. A dumbwaiter system (still in place today) was used for transferring meals and foodstuffs from the basement kitchen to the first floor serving area. The dining room occupied the same place as the present dining room of the Copper Kitchen restaurant, at the southeast end of the first floor. Sister Euphrasia also noted that the stove which was in use in this basement kitchen was gas operated and is still in use at the present-day Ursuline Academy. She recalled that there was a great deal of difficulty in removing the stove from the basement (personal communication). This location differs from that published by Katz (1977:5). According to Mrs. Donald Saunders (personal communication) the southeast portion of the basement was not connected to the northeast section and was separated by thick, rammed earth walls.

Mrs. Saunders also believed the northeast portion of the basement was used as a cistern since it has sloping concrete walls and a concrete floor. Clark (1974:36) discusses the presence of a cistern in the basement of this building 
and, at one time, this may have been that cistern. Since Edwards (1981:57) mentions the presence of a wooden cistern attached to another building (Angel's Ha11) during her stay, it is probable that this concrete cistern was no longer in use, and the space was remodeled into the kitchen. Large storage areas for foodstuffs and other supplies were also located in the basement. Sister Rita, who entered the convent in 1916 and is now retired, noted that this arrangement was in existence in 1916 and had been initiated in 1910 (personal communication with Sister Euphrasia).

Presumably sometime after the departure of Emily Edwards in 1902 the kitchen function was relocated (probably around 1910), leaving Building 3 available for other uses. The relocation of the kitchen was possibily associated with the 1912 construction of the three-story classroom building, which would have permitted the transfer of functions from the basement of the dormitory building to the new building. Relocating the kitchen in one of the main buildings would have added a significant measure of convenience in the operation of the kitchen. With the construction of the St. Mary's Street bridge and the subsequent loss of the laundry and carriage house as depicted by Edwards, a shift in building usage would have become necessary. If the transfer of the kitchen, with its associated storage requirements, had been completed, Building 2 would have been available for use as the carriage house, and Building 3 would have been avai1able for use as a laundry. This would have been accomplished by simply moving these functions "down the row." It seems that Building 3 was the location for the new laundry, based on the presence of a boiler in the add-on and the presence of ironing boards in this building. The association of Building 1 to the laundry operation seems to be based solely on the fact that it has housed a boiler. This boiler may have been used for purposes other than supplying hot water to the laundry, or it may have supplied hot water to the original laundry, which was closer to Building 1 than Building 3 (see Fig. 1).

It is apparent that the Southeast Building Complex served a variety of purposes during the existence of the convent. These buildings underwent various changes and modifications, in both structure and function, as the needs of the convent and its academy changed through the years.

\section{RECOMMENDATIONS}

Although much of the history of the Southeast Building Complex was destroyed by construction activities, which occurred prior to the initiation of this project, significant data were obtained. These data, when combined with previousiy published information, provide new insights regarding the history of the academy during the later half of the 19th century and the early years of the 20th century. The one major significance of this project lies in its contribution toward an increased understanding of the construction techniques and problems, which existed in this important period in the history of San Antonio. It is strongly recommended that detailed archaeological studies precede any further renovation activities at the 01d Ursuline Academy site. 


\section{REFERENCES CITED}

Bexar County, Texas

Bexar County Deed Records (BCDR). Bexar County Courthouse, San Antonio, Texas.

Bexar County Archives-Rebel Properties (BCA-RP). Office of the County Clerk, Bexar County Courthouse, San Antonio, Texas.

$1817 \mathrm{a}$ List and Appraisement of the Property Confiscated from the Rebels.

$1817 \mathrm{~b}$ Inventory of Property Confiscated from the Rebels for the King.

1819a Restitution of a Confiscated House to José Erasmo Seguin.

1819b Property Confiscated from the Rebels, Flood and Damage by the Flood.

Chabot, F. C.

1937 With the Makers of San Antonio. Privately published. Printing by the Artes Graficas, San Antonio, Texas.

Clark, J. W.

1974 Archeological Excavations at Ursuline Academy, San Antonio, Texas, June 1974. Texas Historical Commission, Office of the State Archeologist, Austin, Texas.

Edwards, E.

1981 Stones, Bells, Lighted Candles. Published by the Daughters of the Republ ic of Texas, San Antonio.

n.d. F. Giraud and San Antonio. A biography based on recorded evidence plus circumstantial surmises based on this evidence. Text by Edwards, archival research by Mary C. Newe11. Unpublished manuscript on file, San Antonio Conservation Society, San Antonio, Texas.

Fontana, B. L.

1965 The Tale of a Nail: On the Ethnological Interpretation of

Historic Artifacts. The Florida Anthropologist 18(3):85-90.

Fontana, B. L. and J. C. Greenleaf

1962 Johnny Ward's Ranch: A Study in Historic Archaeology. With the collaboration of Charles W. Ferguson, Robert A. Wright, and Doris Fredrick. The Kiva, Journal of the Arizona Archaeological and Historical Society 28(1-2). 
Ford, Powe11 and Carson Architects and Planners, Inc.

1981 Blueprints and revised drawings dated December 3, 1981. San Antonio, Texas.

Fox, A. A., F. A. Bass, Jr., and T. R. Hester

1976 The Archaeology and History of Alamo Plaza. Center for Archaeological Research. The University of Texas at San Antonio, Archaeological Survey Report 16.

Fox, A. A. and K. Livingston

1979 Historical, Architectural and Archaeological Investigations at the Steiner-Schob Complex, Victoria County, Texas. Center for Archaeological Research. The University of Texas at San Antonio, Archaeological Survey Report 52.

Garner, J. C., Jr.

1967 PreTiminary Adaptive Use Study. Commissioned by the San Antonio Conservation Society, San Antonio, Texas.

1969 Historic American Buildings Survey. Commissioned by the San Antonio Conservation Society, San Antonio, Texas.

n.d. Oed San Antonio Ursuline Academy. Copy on file; San Antonio Conservation Society, San Antonio, Texas.

Gentilz Photograph Collection

Photograph collection on file; Daughters of the Republic of Texas Library, Alamo, San Antonio, Texas.

Gerstle, A., T. C. Kelly, and C. Assad

1978 The Fort Sam Houston Project: An Archaeological and Historical Assessment. Center for Archaeological Research, The University of Texas at San Antonio, Archaeological Survey Report 40.

Green, M.

n.d. Map of the 01d Ursuline Academy Campus at the Turn of the Century. Adapted from research by Mary Green and Emily Edwards. On file; Daughters of the Republic of Texas Library, Alamo, San Antonio, Texas.

Katz, P. R.

19771975 Archaeological Investigations at 01d Ursuline Academy, San Antonio, Texas. Center for Archaeological Research. The University of Texas at San Antonio, Archaeological Survey Report 34. 
Koch, A.

1873 Bird's Eye View of the City of San Antonio, Bexar County, Texas. Map on file; Center for Archaeological Research, The University of Texas at San Antonio and the San Antonio Conservation Society.

1886 Bird's Eye View of San Antonio, Bexar County Texas 1886 Looking Northeast. Map on file; Center for Archaeological Research, The University of Texas at San Antonio and the San Antonio Conservation Society.

McDowe11, C., ed.

1977 Letters from the Ursuline 1852-1853: From Our Beloved Sisters who quitted St. Mary's, April 17th, 1852 to Commence the Mission at San Antonio. Prepared by the Daughters of the Republic of Texas. Trinity University Press, San Antonio.

Mckearin, G. S.

1948 American Glass. Crown Publishers, Inc., New York.

Newmann, T. S.

1970 A Dating Key for Post-Eighteenth Century Bottles. Historical Archaeology $4: 72-73$.

Rams de11, C.

1968 The Legacy of F. Giraud. Texas Parade Apri1:32-34.

Sheridan, Sister Mary Benigus, C.C.V.I., A.M.

1938 Bishop Odin and the New Era of the Catholic Church in Texas, 1840-1860. Ph.D. dissertation presented to the faculty of the Graduate School of St. Louis University in partial fulfillment of the requirements for the Degree of Doctor of Philosophy.

Steinfeldt, C.

1978 San Antonio was: Seen Through a Magic Lantern. Published by the San Antonio Museum Association.

Sturmberg, R.

1920 History of San Antonio and of the Early Days in Texas. Compiled by R. Sturmberg. Published by St. Joseph's Society Press of the Standard Printing Co., San Antonio, Texas.

Southwest Craft Center

1979 Ursuline Convent River Buildings To Be Saved! Occasional publication by the Southwest Craft Center. Apri1. 


\section{Ursuline Academy Files}

Documentary files maintained by Sister Euphrasia of the Ursuline Order at San Antonio, Texas. 


\section{APPENDIX \\ CONTRACT BETWEEN JOHN CAMPBELL AND THE URSULINE ORDER FOR THE CONSTRUCTION OF BUILDING 1}

State of Texas

County of Bexar

Know all men by these presents, that we the undersigned have hereby entered into the following contract of agreement.

Sister Madeleine Superior of the Ursuline Convent and Sister Claud, Depositary, being parties of the First part.

And John Campbel1 Architect and Builder, citizen of San Antonio of the Second part.

The party of the Second part engages and binds himself to put up a building of hard stone, two stories high and about $47 \times 21$ feet. The first story will have six doors, and two windows. Second story seven windows and one door, according to the plan signed. Also a ventilator in both gable-ends. To furnish good materials and Leon Sand, to make two flues without extra charge, to make good building filling well the spaces in the middle of the walls, and to lay the stones in table work, the openings and corners to be made with good solid rock and the stones to be laid as in the quarry bed. Jambs of the doors and windows to be hammer dressed. Over the stone lintels (which will not be less than one foot thick) of all openings, will be placed two stones forming an arch. Also to furnish scaffolding and tools and to finish said work in three months from the 1st of August or forfeit 50 cts. per perch.

The parties of the First part engage themselves to pay four dollars and fifty cents (\$4.50) per perch according to the usual measure; also an extra sum of three dollars $(\$ 3.00)$ for each of the stone lintels for the openings. No deduction will be made for the openings. If a stone should be wrongly placed, it shall be removed at the expense of the Second part.

Every Saturday there will be an account paid which if possible will be three fourths of the work done during the week. When the work will be completed, and measured, part of the amount due will be paid and in two months after the balance of the full amount.

The work done in a good workmanlike manner can be inspected by the Right Rev. C. M. Dubuis.

In testimony thereof we have hereunto signed our names in the City of San Antonio this the 3rd day of August A. D. 1872.

Wilneu E. Buffard

John Schneider
Sr. de St. Madeleine

Sr. de St. Claude Depositary

John M. Campbe11 


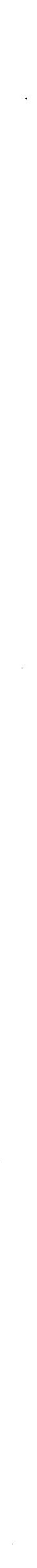




